\title{
Sugar Beet Cultivation in India: Prospects for Bio-Ethanol Production and Value-Added Co-Products
}

\author{
Ashutosh Kumar Mall ${ }^{1}$ - Varucha Misra ${ }^{1} \cdot$ Santeshwari $^{1}$ - A. D. Pathak ${ }^{1}$. \\ Sangeeta Srivastava ${ }^{1}$ (D)
}

Received: 18 January 2021/Accepted: 11 May 2021/Published online: 7 July 2021

(C) Society for Sugar Research \& Promotion 2021

\begin{abstract}
Sugar beet is an important crop in the advent of COVID 19 as it has a high potential for ethanol production in less growth span. The life cycle of this crop is of five to six months with a root yield of $60-80 \mathrm{t} \mathrm{ha}^{-1}$ and sugar content of $15-17 \%$. Sugar beet is known as a temperate crop of short duration grown in the month of September to October and harvested in April and May, but successful efforts have been made in establishing this crop for Indian agro-climatic conditions. India stands to gain from capitalizing on the potential of sugar beet for sugar, ethanol, and fodder. It offers the increment in the farmer's income especially hill farmers with respect to seed production of this crop in India The crop has been bestowed with a natural endowment of reclaiming saline soils which will help in cultivating the Indian saline areas. The crop is full of carbohydrates content which is being used for multiple purposes giving value addition to the crop. The green top and, wet and dry pulp are a good source of fodder material for lactating animals like cattle. Beet pulp is another good source as silage feed and as an adhesive in beauty products as well as in printing ink. An amount of $5250 \mathrm{~L}$ of ethanol per hectare crop can be produced. Due to $30 \%$ galacturonic acid content, the dry beet pulp can also be used as a source of Vitamin C. Lactic acid is also being produced from the juice of sugar beet through fermentation. The pectin content of this crop is useful in paper and board manufacturing industries as a raw material and also in dishwashing detergents and leather production. The fiber content works as dietary fibers which are used in meat and baking
\end{abstract}

Sangeeta Srivastava

sangeeta.iisr@gmail.com

1 Division of Crop Improvement, ICAR-Indian Institute of Sugarcane Research, Lucknow 226 002, U.P., India industries as important ingredients in food commodities. The vinasse produced as an industrial by-product is useful as a fertilizer. Sugar beet tails and other parts have also been used in biogas production in some countries. Intercropping of this crop with other crops is an added benefit of this crop. New prospects are also available for this crop in pharmaceutical industries and material sciences in times to come.

Keywords Ethanol · Fodder - Sugar beet - Sugar . Value addition

\section{Introduction}

Sugar beet is cultivated in 41 countries of the world covering an area of 8.1 million hectares (Mehdikhani et al. 2011). The countries Russian Federation, France, Germany, United States of America, Turkey, Poland, China, Egypt, Ukraine, and United Kingdom are top ten sugar beet producers (FAO 2019). Biancardi et al. (2010) had showed that the annual use of sugar beet has been enhanced by approximately $1.5 \%$ predominantly in countries where the population is more such as China and India. As per USDA (2008) sugar beet contributes to $40 \%$ of world sugar trade. However, Zicari et al. (2019) revealed the contribution of beet in the world's sugar production accounts for nearly $30 \%$. Domestication of beet as a leafy vegetable and root crop is known from prehistoric era, but its production as a crop is new to many countries like India (Panella and Kaffka 2011). It was the European sugar industry which extracted sugar from this crop and in the nineteenth century, the spread of this industry was boosted up due to the increased demand of sugar caused by British blockade of continental Europe (Francis 2006). It is a biennial plant 
implying the formation of the root in the first year and flower production in second year. This crop owns a wider consistency with resistance to water stress (Mall et al. 2018a), salt stress (Misra et al. 2020) and frost (Webster et al. 2016). Sugar beet, a sucrose rich crop, is known for its multifarious uses in the industrial field (Misra et al. 2018). It competes well with sugarcane crop in European countries for production of sugar and ethanol. Sugar beet is mainly cultivated in Europe and in very lesser amount in Asia and North America (Pathak et al. 2014). Approaches of genetic and agro-technological improvements have now extended its frontiers to higher latitudes of sub-tropics and tropical irrigated winter crop. It is a temperate crop and is the only crop that has now been established for production in tropical countries like India (Ford-Lyod et al. 2008; Ford-Lyod and Williams 1975). This crop holds promise in Indian agro-climates with increasing demands and needs of bio-ethanol and sugar (Pathak et al. 2017). In India, the production of sugar and ethanol is solely dependent on sugarcane crop which makes the crop over burdened with the high demands and needs of the population (Mall et al. 2018b). Sugar beet crop can augment sugarcane to fulfill the future requirements of India (Mall et al. 2018c). Sugar beet was originated as a fodder beet having low amount of sugar content but the continuous selection and improvement has given rise to the present diploid hybrid sugar beet varieties which possess high sugar content (16-19\% on an average). This implies that sugar beet cultivation in India may help in enhancing the sugar recovery (reaching as close to $13-15 \%$ ) at mills.

\section{Historical Perspective}

Sugar beet was introduced in India in 1950s. Exploratory trials for the root and seed crop were carried out by ICARIndian Institute of Sugarcane Research (IISR), Lucknow, at identified suitable sites in India. The first trial was conducted in India during 1959-1969 on exotic varieties of sugar beet with systematic multi-location testing with the suitable package and practices. This concept was established by All India Coordinated Research Project on Sugar beet by the Indian Council of Agricultural Research (ICAR) in 1970 which had three main centers at Pantnagar, Kanpur, and IISR Lucknow (Nodal Center). ICAR established five sub-centers at Jalandhar, Hissar, Sriganganagar, Phaltan (Maharashtra) and Vegetable Research Station, Kalpa, and a new center at BCKV, Kalyani (WB) was added in the $7^{\text {th }}$ five-year plan. In the view of research, 1970s and 1980s were the golden era of sugar beet with intense research activities in multiple aspects like agronomical practices, germplasm evaluation, varietal trial, entomological, pathological, and agricultural engineering. The complete package and practices for sugar beet cultivation were developed along with several technologies of plant protection, cultural practices, and mechanization in sugar beet. The sugar beet cultivation practices in saltaffected soils were developed at Sundarbans (West Bengal) for the sub-tropical region of India (Anonymous 2008), and found some varieties, viz., Pant S 1, Pant S 10, IISR Comp1, IISR 2, and Magnapoly that were suitable to grow in alkaline soil conditions. The utilization of sugar beet for alcohol production has been worked at Sundarbans. During 1976, All India Coordinated Research Project on sugar beet was transferred to G.B.P.U.A.\&T, Pantnagar, but during VIII five-year plan, AICRP on Sugar beet was continued as Network Research Project with its headquarters at IISR, Lucknow, and five centers at Lucknow, Mukteshwar, Sriganganagar, Sundarbans (under the Kalyani Centre) and Kalpa. Since 1970, sugar beet is being cultivated on a commercial scale at Sriganganagar in Rajasthan. A cane/ beet sugar factory was established at Sriganganagar (Rajasthan) for commercial exploitation of sugar beet. The highest sugar recovery obtained from sugar beet was 11.32\% during 1978-79 (Anonymous, 1978-79). Development of diploid/polyploid varieties/hybrid was a major objective in sugar beet research at IISR, Lucknow and during 80's IISR developed two hybrids (LK HY-1 and LK HY-2), one composite (IISR Comp-1) and one synthetic (LKS-10). Multi-location testing of these hybrids was also conducted by the IISR, Lucknow. During this era, breeder seed production of amelite variety LS-6 was done at Sugar beet Breeding Outpost, Mukteshwar. An open-pollinated diploid Russian variety seed namely Ramonskaya-06 (R06) was found suitable to grow in India. Several exotic germplasm were evaluated against the best available check Ramonskaya (R-06). Some anisoploid varieties were also found suitable. At that time R-06 was under cultivation for several years but unfortunately, performance of this variety genetically deteriorated. So, IISR, Lucknow imported R-06 seed from USSR for genetically maintenance of this variety. Under the strict supervision of breeders foundation seed and certified seed were produced at different centers. National Seeds Corporation (Sriganganagar) had undertaken the seed production of R-06 and after that Himachal Pradesh taken the production authority. Network Research Project on Sugar beet was merged with AICRP (Sugarcane) during December, 1994. A joint meeting of AICRP (S) and Network Research Project on Sugar beet was held in 1998 at Vasantada Sugar Institute (VSI), Pune, and it was decided to phase out the sugar beet project because this crop was not much popularized as expected. In view of several benefits of sugar beet, IISR, Lucknow is still continuing the sugar beet research and seed production at its Outpost in Mukteshwar in Kumaon hills. Development of tropicalized sugar beet varieties and seed production was taken up by multinational sugar beet seed companies under 
the direction of Syngenta Company in 2004. At the same time, ICAR also launched a Network Research Project to assess the feasibility of new sugar beet varieties under tropical conditions. Sporadic establishment of sugar beet processing units during 2008-2012 made the prospects of sugar beet look better up. During this period a pilot plant was developed by VSI in Saamarth which later moved to Islampur. Ethanol plants were developed in Maharashtra and Karnataka and a sugar factory was established in Punjab.

A historical chronology of various historical events in sugar beet research in India has been illustrated in Fig. 1.

\section{Sugar Beet Cultivation in India}

India is one among the fortunate countries bestowed with vagaries of agro-climatic conditions that help in the cultivation of sugar beet crop which is now been established in tropical and sub-tropical India. Favorable time for sugar beet cultivation starts from the end of September to mid of October (Deol and Kanwar 1975). The total life span of this crop is of 5-6 months. Mathuria and Bhoj (1977) demonstrated that both early and late sowing of sugar beet causes a negative impact on root yield. Sugar beet flourishes well in clayey loam, loam, or sandy loam soils, i.e., neutral to slightly alkaline in nature. Soils having $\mathrm{pH} 7.0-8.5$ are the most favorable $\mathrm{pH}$ condition; however, this crop can be grown at high $\mathrm{pH}$ of $8.0-9.6$ due to its salt tolerance property. In the Deccan tracts of Maharashtra, Karnataka, Andhra Pradesh, and Tamil Nadu, sugar beet can be grown on black cotton soils. A fairly cool climate with an adequate amount of rainfall, bright sunshine during different phases of growth helps in flourishing healthy sugar beet crop (Pathak et al. 2014). The optimum condition for seed germination and root growth is around $25^{\circ} \mathrm{C}$ and $20^{\circ} \mathrm{C}$, respectively (Dubetz and Russell 1964). Low soil temperatures during the early growth phase were reported to have a positive impact on root weight (Smit 1983). The fertilizer requirement ranges from 100 to $120 \mathrm{~kg} \mathrm{~N} \mathrm{ha}^{-1}$ and $60 \mathrm{~kg}$ $\mathrm{P}_{2} \mathrm{O}_{5} \mathrm{ha}^{-1}$ along with farmyard manure at the rate of 10-15 tonnes $\mathrm{ha}^{-1}$. Green manuring and organic manures may also be added to the crop. Late usage of nitrogen in sugar beet crop has been reported to affect the canopy size and amount of nitrogen content in the plant (Malnou et al. 2008). Irrigation is an essential requirement for the healthy crop. The time of first irrigation supply is important as it helps in the establishment of seeds in the soil. Thus while supplying irrigation to the crop, care must be given that water should not flow over the ridges. Irrigation supply is also dependent on factors like soil type, moisture content, rainfall, etc. Recommended irrigation supplies in sugar beet are 10-12 irrigations. Irrigations supplied at 75 and $50 \mathrm{~mm}$ cumulative pan evaporation (CPE) resulted in the highest yield of this crop (Table 1).

Sugar beet faces competition with weeds from germination to harvest. If weeds were allowed to grow beyond

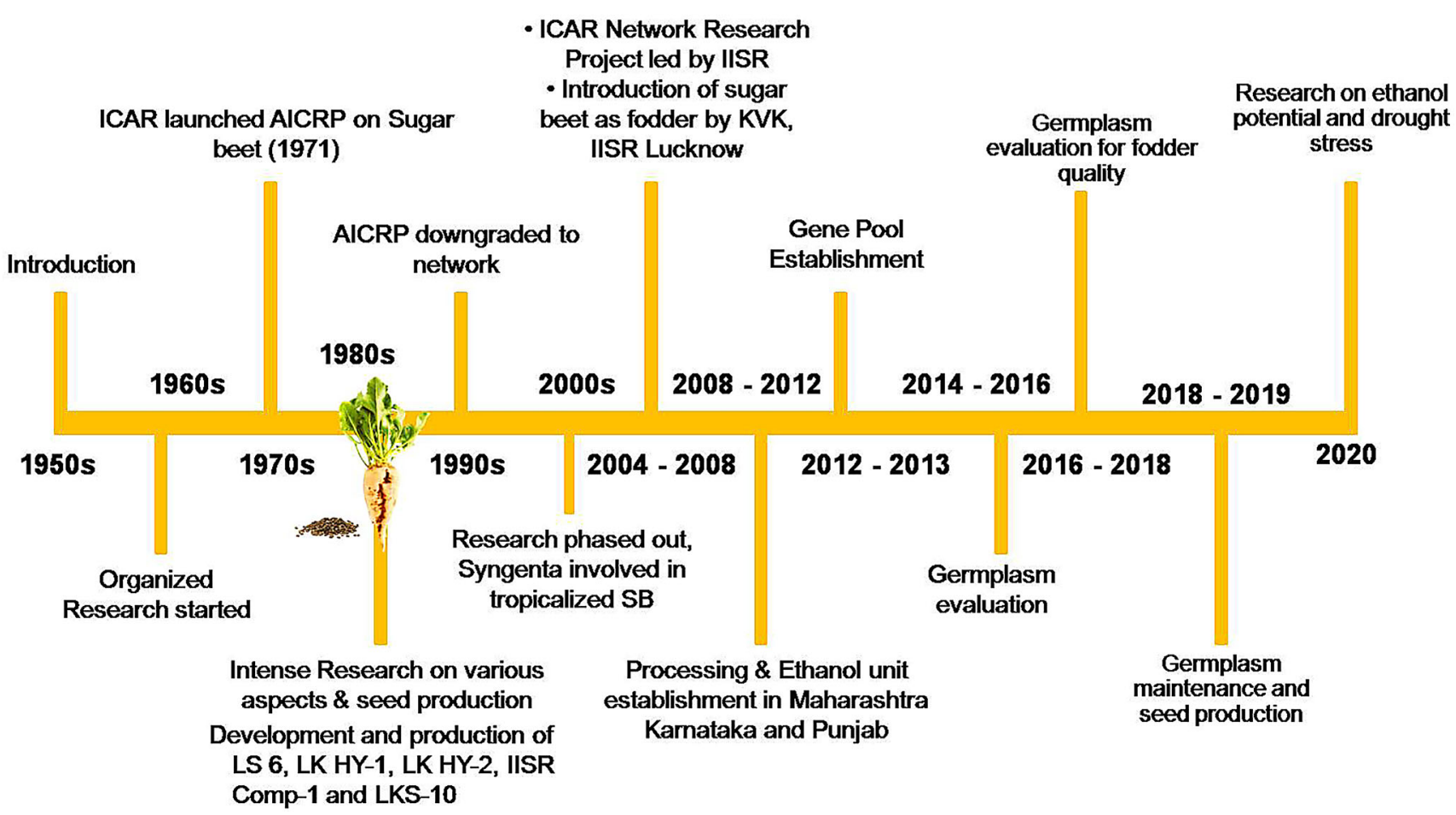

Fig. 1 Sugar beet timeline depicting chronology of various research events in India from pre-historic era to present 
Table 1 Effect of Irrigation schedule on sugar beet yield $\left(\mathrm{t} \mathrm{ha}^{-1}\right)$ over the season. Source: APCess Network Project Report 2004-2008; Network project in sugar beet 2004-2005

\begin{tabular}{lrlllll}
\hline $\begin{array}{l}\text { Irrigation }(\mathrm{mm}) \text { at cumulative pan } \\
\text { evaporation }(\mathrm{CPE})\end{array}$ & \multicolumn{2}{l}{ State } & & \multicolumn{2}{l}{ Varieties } \\
\cline { 2 - 3 } & $\begin{array}{l}\text { VSI, } \\
\text { Pune }\end{array}$ & ARS, & & HI & LS \\
& 99.1 & 41.0 & & 37.0 & 35.6 \\
\hline 100 & 102.2 & 42.8 & & 42.0 & 36.5 \\
60 & 91.8 & 49.1 & & 46.5 & 40.3 \\
50 & 75.9 & 48.4 & & 49.7 & 45.7 \\
\hline
\end{tabular}

60 days of sowing, yield losses in sugar beet have been reported. Motiwale et al. (1991) had illustrated that uncontrolled weed growth causes a reduction of $35-54 \%$ in yield. At the early growth stage, one manual weeding followed by two/three shallow hoeings/weedings favors good growth of the crop. Earthing up is also necessary along with the last dosage of nitrogen fertilizer in the month of December. Thinning is required in sugar beet multigerm seeds, which produces $2-3$ plants/seed while it is not in the case of monogerm seeds. The most suitable time for singling and thinning is after 3-4 weeks of sowing i.e., 4-6 leaf stage crops. The plants after thinning should be placed at a distance of $20 \mathrm{~cm}$ from each other. Table 2 depicts the cultivation practices and their month of performance.

\subsection{Seed Production in Hills}

Sugar beet requires thermal induction for flowering and seed production (Kapur et al. 1986). This requirement lacks in sugar beet grown in plains which prevent it to flower under such a condition. Due to this reason, seed production has been standardized in places at higher altitudes $(>5000$ feet) where favorable weather conditions prevail
(Srivastava et al. 1983, 1986). These places were Srinagar (Jammu and Kashmir), Mukteswar \& Ranichauri (Kumaon Hills), Darjeeling (West Bengal), Shimla \& Kalpa (Himachal Pradesh), Auli (Garhwal Hills). At all these places seed production technology was established (Pathak et al. 2011) and successful seed production of Ramonskaya-06 (R-06), a Russian variety, was performed followed by the development and production of indigenous varieties, viz., IISR Comp-1 and LS-6 (developed by IISR Lucknow, Uttar Pradesh) and Pant S-10 (developed by GPUAT Pantnagar, Uttarakhand) (Pathak et al. 2014). Kapur et al. (2000) revealed that at these places high-temperature tolerant varieties were also developed and maintained along with the production of diploid varieties recommended for general cultivation areas. Kalpa center in Himachal Pradesh was routinely producing foundation seeds of multigerm unpelleted varieties with mass multiplication by National Seeds Corporation (Pathak et al. 2014). Presently ICAR-IISR Sugar beet Outpost, Mukteshwar is producing and maintaining sugar beet seeds (Fig. 2).

Sugar beet seeds are produced either by in situ method or transplanting method. In situ method requires overwintering conditions in the field for the beet flowers to blossom and produce seed. Due to its overwintering requirement, it is often termed as an overwintering method. In the transplanting method, selected stecklings (or young roots) are uprooted in the first season and stored in trenches for overwintering conditions followed by thermal induction. The stecklings are replanted during overwintering conditions in the next season for the production of flowers and seeds. This practice is generally being performed in sugar beets grown in the plains of India (Kapur et al. 1986). An important practice is to cut one-third of the top and root portion prior to planting these retaining, only $10 \mathrm{~cm}$ of leaves. Root weight of 7-16 g with a pair of 5-10 leaves along with the height of the plant as $22-26 \mathrm{~cm}$ is the

Table 2 Sugar beet cultivation practices developed by IISR, Lucknow

\begin{tabular}{|c|c|}
\hline Cultivation practices & Month/requirement \\
\hline Sowing & End of September-mid of October \\
\hline \multirow[t]{2}{*}{ Plant to plant distance } & At the time of sowing: $10 \mathrm{~cm}$ \\
\hline & After thinning in multi-germ seeds: $20 \mathrm{~cm}$ \\
\hline Germination & Within a week \\
\hline Thinning (only in multi-germ seeds) & After 3-4 weeks of sowing \\
\hline Earthing up & December \\
\hline Fertilizer dosage & $\begin{array}{l}100-120 \mathrm{~kg} \mathrm{~N} \mathrm{ha}{ }^{-1} \text { in two equal splits; one at the time of sowing } \\
\left.\text { and other during earthing up (@40 kg ha }{ }^{-1}\right) ; 60 \mathrm{~kg} \mathrm{ha}^{-1} \mathrm{P}_{2} \mathrm{O}_{5} \text { at time of planting }\end{array}$ \\
\hline Weeding & 30 DAS \\
\hline Herbicide spray & Rifit @2 kg ha ${ }^{-1}$ or Alachlor @ 1 Liter ha ${ }^{-1}$ \\
\hline Harvesting & Six months from day of sowing \\
\hline
\end{tabular}




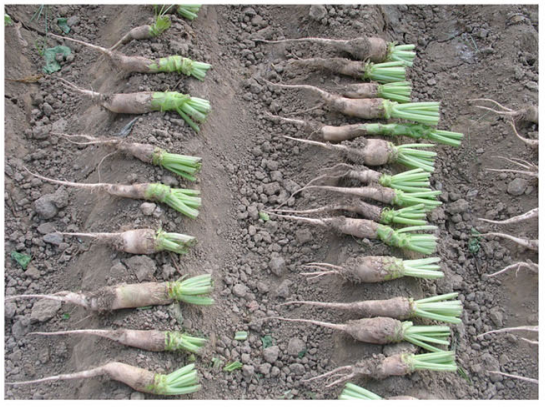

(a) Settlings for transplantation

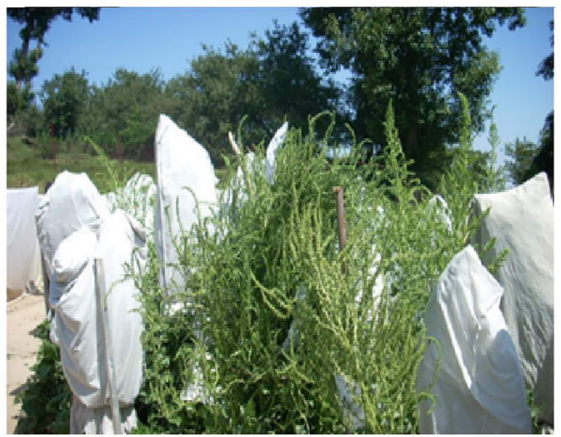

(d) Hybridisation

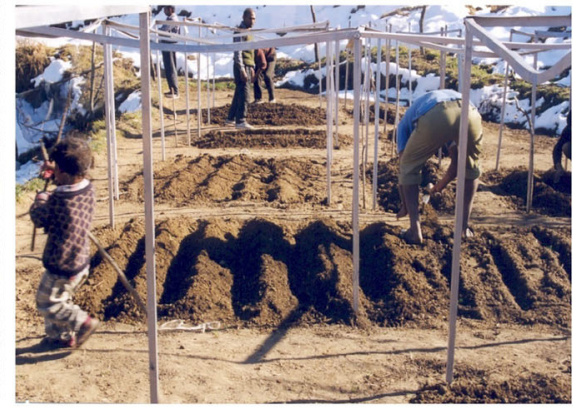

(b) Field preparation

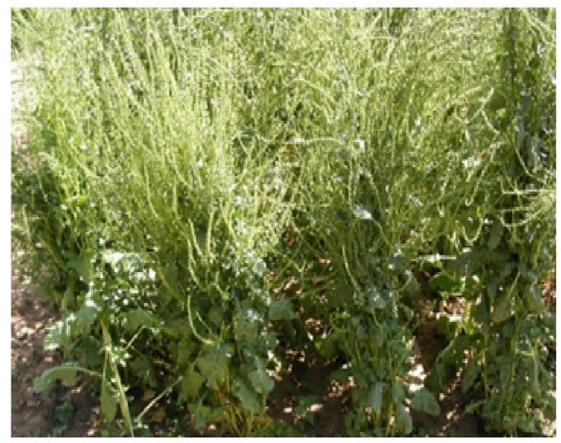

(e) Seed in open pollinated crop

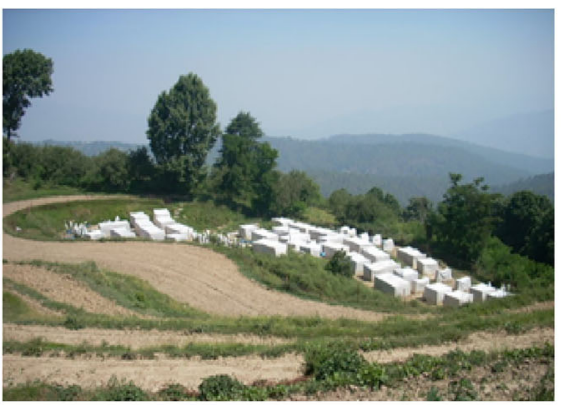

(c) Pollination

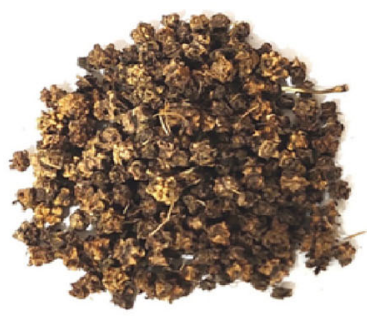

(f) Seeds

Fig. 2 a-f Seed production at sugar beet breeding outpost, Mukteshwar

requirement for transplanting method as reported by Balan et al. (1991). Development of seed takes place inside the fruit of sugar beet. Seed comprises of pericarp and operculum with an ovary cap. The sugar beet seed comprises of two or five embryos supported by diploid perisperm rather than triploid one (Agrawal and Rakwal 2012; Jagosz 2018), due to which it is termed as multigerm seed. Conversely, the production of monogerm seeds (single embryo) occurs through mechanical means (OECD 2006).

\section{Development of Indigenous Varieties of Sugar Beet for Commercial Production}

Srivastava (1995) reported that one diploid multigerm indigenous germplasm, named LS-6, has been developed and released for commercial purposes favorable for growth under Indian agroclimatic conditions. This genotype was openpollinated and developed through mass selection. It is tolerant to Sclerotium root rot (caused by $S$. rolfsii) and to high temperatures along with retaining low impurity index (Mukhopadhyay 1971; Srivastava 1995). Two other promising diploid elite lines, viz., IISR 2 and LS-7, were developed at GBPUAT, Pantnagar, Uttarakhand, for cultivation in India. Both the elite lines were selected through mass selection (Anonymous 1988). Development of composites and synthetic germplasm were also produced at IISR Lucknow and GBPUAT, Pantnagar. IISR Composite
1 (IISR Comp-1), Pant Composite 1 (Pant Comp-1), Pant Composite 3 (Pant Comp-3) were composite germplasm while LKS-10 was synthetic germplasm identified. Out of these, IISR Comp-1, Pant Comp-3, and LKS-10 were identified as high promising sugar beet elite lines. IISR Comp-1 was another variety that was recommended for commercial cultivation in India. Srivastava (1990) and Srivastava (1991) reported that two other diploid elite lines were developed via three ways cross hybrids, viz., Lucknow Hybrid 1 (LK HY 1) and Lucknow hybrid 2 (LK HY $2)$. Both these elite lines showed superiority with composite and synthetic sugar beet germplasm (Table 3).

\section{Ethanol Production from Sugar Beet}

The initial operations for ethanol processing are washing of sugar beet roots so that all the dust and mud particles are removed. The beet roots are thinly sliced into round pieces which are known as cossettes. This process helps in extracting out the sugar content from the roots. The cossettes were dipped in hot water for juice extraction after which the juice was fortified with nutrients. The adjustment of $\mathrm{pH}$ is required for lesser microbial attack and the $\mathrm{pH}$ value is adjusted to 4.5 (Paroha and Swain 2020). Sterilization of juice is the next step after $\mathrm{pH}$ adjustment which requires a pressure of $15 \mathrm{psi}$ for a period of $15 \mathrm{~min}$. On the cooling of the juice, the fermentation process is initiated by 
Table 3 Relative performance of diploid sugar beet hybrids, compared with composites and synthetic germplasm. Source: Srivastava (1995)

\begin{tabular}{llll}
\hline $\begin{array}{l}\text { Composited/ } \\
\text { Synthetics }\end{array}$ & $\begin{array}{l}\text { Root yield (t } \\
\left.\mathrm{ha}^{-1}\right)\end{array}$ & $\begin{array}{l}\text { Top yield }(\mathrm{t} \\
\left.\mathrm{ha}^{-1}\right)\end{array}$ & $\begin{array}{l}\text { Sucrose } \\
(\%)\end{array}$ \\
\hline LK HY 1 & 121 & 133 & 101 \\
LK HY 2 & 94 & 102 & 106 \\
IISR Comp-1 & 117 & 109 & 110 \\
LKS 10 & 114 & 101 & 108 \\
\hline
\end{tabular}

addition of yeast for the production of ethanol (Kumar et al. 2015). The raw juice is thermally unstable at temperatures above $85{ }^{\circ} \mathrm{C}$. Milk of lime and carbon dioxide are used for juice purification. Anaerobic fermentation is responsible for the production of ethanol from sugar beet roots (Gressel 2008). The enzymatic hydrolysis is trailed after the fermentation process completes. Commercially available yeasts help in the conversion of glucose (produced after enzymatic hydrolysis through invertase enzyme) to ethanol under an environment where oxygen is deficit. Atiyeh and Duvnjak (2003) revealed that Saccharomyces cerevisiae ATCC 36859 is one of the microbes which have efficiency towards higher production of ethanol from beet molasses. Besides, certain bacteria like Spirochaeta, etc., are also helpful in converting glucose to ethanol by the Embden Meyerhof pathway under an anaerobic environment. Turquois et al. (1999) showed that direct usage of pulp or root is not as good for ethanol production as sugars are released in a very slow manner into the fermented solution and the beet storage for the longer duration further adds to sugar loss through enzymatic action (Bergall et al. 1997). Raw sugar beet juice is a good raw material as it contains $85-90 \%$ of sugars and can undergo fermentation with slight changes and adjustments in the $\mathrm{pH}$ of the juice. However, microbial infestation and the problem of storage of raw juice for the longer period are the two restrictions while using thick juice for ethanol production (Tan et al. 2015). Gumienna et al. (2014) stated that thin juice of sugar beet results in relatively higher ethanol yield than thick juice or pulp. Rankovic et al. (2009) illustrated that thin juice of sugar beet can be used for ethanol production but prior to using the juice is evaporated to give a higher concentration of sugars and inhibition of microbial attack. Traditionally, molasses, a by-product after crystallization, are also used for the production of ethanol from sugar beet (Kumar et al. 2009).

Mohan (2019) revealed that LS 6, SZ 35, and PAC 60008 had root yield of 80 tonnes per hectare on an average with an ethanol production ranging from 90 to $100 \mathrm{~L}$ per tonne under Indian conditions. Paroha and Swain (2020) revealed the ethanol yield from sugar beet grown under
Indian conditions illustrating the variation between theoretical and practical ethanol yield (Table 4).

\section{Alternative Uses of Sugar Beet}

Sugar beet is one such crop which has almost zero wastage (Tomaszewska et al. 2018). Starting from its leaves, roots, pulp, molasses, vinasse, all the plant parts as well as their left over are some or in other way utilized for industrial purposes of different sectors (Finkenstadt 2013). The value-added products of sugar beet have been described in figure (Fig. 4).

\section{As Bio-Ethanol Producer}

The natural resources of petrol and other energy sources are depleting rapidly and as such attention of the scientists all over the world is focused to find out alternative sources. Sugar beet due to its high yield, sugar content and short duration may prove to be a good source of alcohol (AICRP on sugar beet report, 1989-90). Theurer et al. (1987) demonstrated that ethanol content in sugar beet is relatively higher than that in fodder beet. Gibbons and Westby (1987) revealed that $4.83 \%$ ethanol production can be obtained from various varieties of fodder beet. Ethanol obtained from wheat was $2688 \mathrm{~L}$ per hectare while in sugar beet this amounts to $5250 \mathrm{~L}$ per hectare, implying the high potential this crop persist (Anonymous 2010). Blazek (2007) showed that $1 \mathrm{~kg}$ of sugar beet produces $0.126 \mathrm{~L}$ of ethanol content in Indian conditions. Root yield and sucrose content are the factors on which ethanol content is determined. Srivastava et al. (2008) illustrated the importance of these two factors and showed that the varieties having high root yield and sucrose content have more ethanol production. Mehdikhani et al. (2011) also estimated ethanol content in different sugar beet varieties while several indigenous varieties have also good sugar and ethanol recovery (Tables 5 and 6). Icoz et al. (2009) illustrated the ethanol production of sugar beet in comparison with other crops (Table 7). Salazar-Ordonez et al. (2013) revealed the importance of sugar beet production with reference to ethanol production which will be a good option for reducing the dependency of crude oil import as well as other import of raw materials for the generation of ethanol.

A publication of FAO (2008) stated that production of ethanol from sugar beet roots ranges between 100 and 120 $\mathrm{L}$ per tonne on a fresh weight basis while production via ethanol fermentation had $110 \mathrm{~L} /$ tonne. On a dry weight basis, one ton of sugar beet had 3.89 GJ of energy. Von Felde (2008) has estimated that anaerobic digestion methods for whole beets to produce bio-methane would produce $137 \%$ more energy as compared to fermentation of sugar beet to ethanol. Shapouri et al. (2006) showed that ethanol 
Table 4 Ethanol content in sugar beet grown under Indian conditions. Source: Paroha and Swain (2020)

\begin{tabular}{ll}
\hline Parameters & Amount \\
\hline Quantity of beet roots (Kg) & 3 \\
Total volume of juice obtained (liters) & 5 \\
Total reducing sugars content (\%) & 11.4 \\
Theoretical ethanol yield (\%v/v) & 7.34 \\
Practical ethanol yield (\%v/v) & 6.10 \\
Ethanol Yield (L/ton) & 101.6 \\
Fermentation efficiency $(\%)$ & 83.1 \\
\hline
\end{tabular}

production from sugar beet on a wet basis was $103.5 \mathrm{~L}$ per tonne. The study of von Felde (2008) revealed that higher energy was required for the production of biomethane in comparison with that required for the production of bioethanol.

\section{As Fodder Material}

Wet and dried pulp, a by-product, is a supplement as fodder material to mulch animals like cattle where it increases milk production by 6 to $10 \%$. Castle (1972) showed that the dried molasses pulp could be a good ingredient in the diet
Fig. 3 Indegenous germplasm of sugar beet identified for various traits under Indian agroclimatic condition

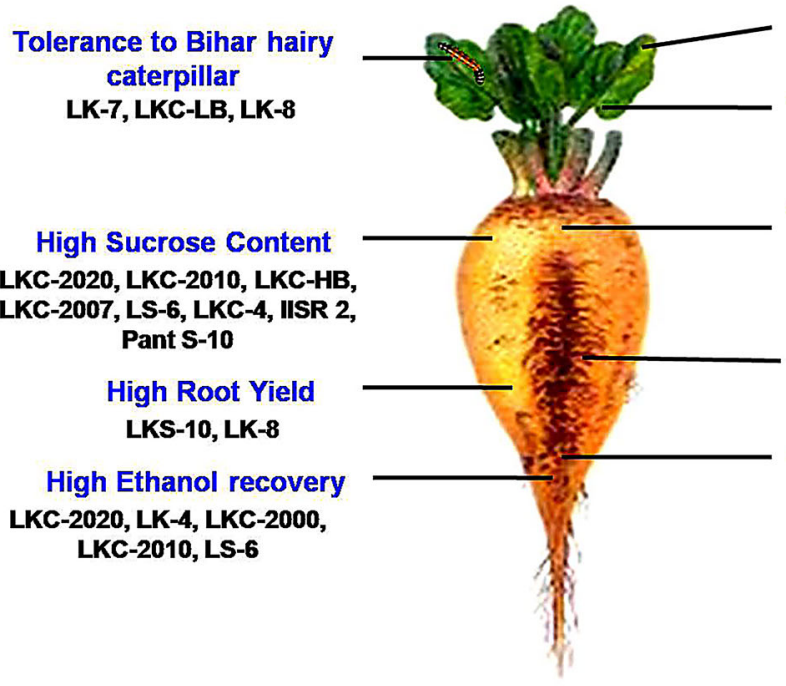

Top Yield

LK-8

Tolerance to Cercospora leaf spot LS-6, IISR 2

Tolerance to root rot

LK-08, LS-6, IISR Comp-1 LKS-10, LK-27

Tolerance to high temperature

LS-6, LS-7, Pant S-10, IISR Comp-1, IISR 2

Tolerance to Salt stress

LS-6, IISR Comp-1, Pant Comp-3

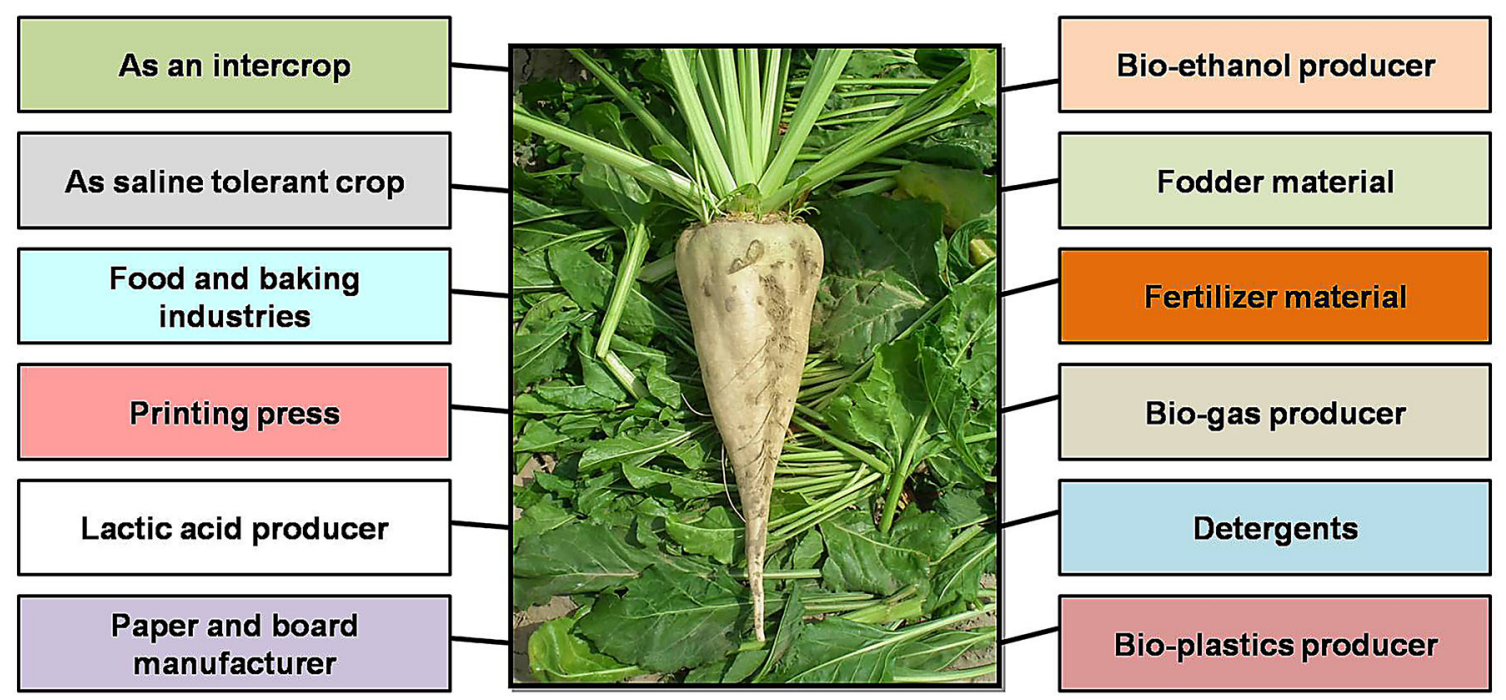

Fig. 4 Multifarious and alternative uses of sugar beet crop 
Table 5 Ethanol recovery potential in Sugar beet germplasm. Source: Mehdikhani et al. (2011)

\begin{tabular}{lllll}
\hline Varieties & Sucrose content $(\%)$ & Root yield $\left(\mathrm{t} \mathrm{ha}^{-1}\right)$ & $\begin{array}{l}\text { Ethanol from } \\
\text { root }\end{array}$ \\
\cline { 4 - 5 } & & & $\mathrm{L} \mathrm{ton}$ & $\mathrm{L} \mathrm{ha}$ \\
\hline IR2 & 16.6 & 87.49 & 105.60 & 9285 \\
37RT & 16.5 & 65.67 & 105.70 & 6901 \\
BR1 & 16.4 & 61.68 & 104.80 & 6489 \\
Shirin & 17.8 & 58.14 & 113.20 & 6337 \\
\hline
\end{tabular}

Table 6 Ethanol recovery in Indigenous Sugar beet germplasm. Source: Annual Report 2018-19 ICAR-IISR)

\begin{tabular}{llll}
\hline Varieties & Sucrose content $(\%)$ & Brix $(\%)$ & Ethanol recovery $(\%)$ \\
\hline LKC 2000 & 20.1 & 20.7 & 8.1 \\
LKC 2006 & 14.5 & 17.9 & 7.7 \\
LKC 2007 & 21.1 & 20.3 & 8.2 \\
LKC 2010 & 18.7 & 18.4 & 7.5 \\
LS 6 & 19.6 & 20.6 & 8.5 \\
\hline
\end{tabular}

given to the lactating cows. The dried molasses beet pulp (DMBP) constitutes $79 \mathrm{~g}$ digestible crude protein $\mathrm{kg}^{-1} \mathrm{DM}$ with a release of $12.5 \mathrm{MJ}$ metabolizable energy (Kelly 1983). This product acted as a rich source of nutrients as compared to the diets consisting of grass or hay (Castle et al. 1982). The nutrient value of dried un-molasses sugar beet pulp (SBP) and dried pulp constituting $40 \%$ molasses as a diet ingredient is almost equivalent. The milk yield produced from lactating cows having an intake of these pulps has not shown any significant difference (Hemingway et al. 1986), whereas Parkins et al. (1986) revealed that the variation in the yield and fat concentration in cows who were having an intake of fresh pressed un-molasses SBP with ones having dried molasses pulp. Furthermore, the production of fat and protein per day in cows consuming a different diet was not significant (Parkins et al. 1986). The high crude fiber content present in beet pulp has also a high potential as ruminant feed due to its digestive power and has revealed beneficial effects on milk fat. Bhattacharya et al. (1975) reported that growing fattening sheep fed on a diet that contained $45 \%$ DSBP $+45 \%$ corn gained faster and required less feed per unit of gain than those fed on either $90 \%$ corn or DSBP. There is an additional need for forage or supplementary fiber to make the feed completely nutritious and palatable such as molasses. Mahmoud and El-Bordeny (2016) had shown that SBP (partial or whole) may also replace the application of yellow corn on Barki lambs.

Silage is another material obtained from beet during fermentation processing in a controlled environment. Due to the presence of $80-85 \%$ moisture content, the beet pulp can be used as silage feed for animals particularly livestock. El-Badawi and El-Kady (2006) showed 3\% ureated sugar beet pulp as an ingredient in diets provided to the lambs had better roughage than provided by Berseem. The rich Lucerne content found in the beet pulp makes it highly nutritive and a valuable source. Murray et al. (2006) reported that equine diets containing Lucerne and sugar beet pulp had higher nutritive value than Lucerne solely possess. Besides, the vinasse obtained from this crop has also been useful as feeding material for ruminants, pigs, and poultry. Kaffka and Grantz (2014) had reported that the production of monosodium glutamate involves the use of sugar and molasses from sugar beet.

Sugar beet leaf is a calorific feed with a growth promoter for livestock. A Previous study proved that cattle effectively fattened on rations of beet tops with slight or no grains included. Generally beet tops are compared with alfalfa grass; blooming beet tops can replace grass as well as grains (Maynard 1948).

\section{As Fertilizer}

During the processing of sugar beet, vinasse is produced as a by-product that can be used as fertilizer for crop growth (Martin-Olmedo et al. 1996). The high potash content and other essential nutrients like $\mathrm{N}$ and $\mathrm{P}$ make it a good fertilizer. Sugar beet vinasse also contains some amount of trace nutrients like manganese, iron, and boron. This byproduct acts as a source material for the production of potassium sulfate, organic fertilizer containing a little amount of chlorine and a high amount of sulfur (MoranSalazar et al. 2016). Another by-product obtained during

Table 7 Ethanol production in different crops. Source: Icoz et al. (2009)

\begin{tabular}{lccccc}
\hline Crops & Sugar beet & Wheat & Triticale & Rye & Corn \\
\hline Total production $(\mathrm{m} \mathrm{ton})$ & 27.8 & 21.4 & 4.1 & 4.1 & 3.3 \\
Average yield $\left(\mathrm{t} \mathrm{ha}^{-1}\right)$ & 61.7 & 7.2 & 5.6 & 4.9 & 9.2 \\
Ethanol yield $\left(\mathrm{m}^{3} \mathrm{ha}^{-1}\right)$ & 6.6 & 2.8 & 2.2 & 2.0 & 3.5 \\
\hline
\end{tabular}


the juice purification stage is the lime which acts as a good conditioner for soil used for agricultural purposes (Fares et al. 2016).

\section{As Intercrop with Other Crops}

Sugar beet has great potential as an intercrop. It helps in decreasing pest infestation and weed incidence (Baumann et al. 2001). Intercropping of sugar beet with several pulses and cereals is a better option as a management practice for weed growth due to lesser availability of radiation for the growth of weeds (Baumann et al. 2001). Sugar beet sunflower intercropping also showed management of incidence rate of insect pests along with positive response towards soil health and improvement (Stoyanov et al. 1997). This also provides high gross returns to the growers (Lal and Mukerji 1998). Intercropping of sugarcane with sugar beet gives greater revenue than the crops grown solely with the balanced consumption of NPK $\left(250 \mathrm{~kg} \mathrm{ha}^{-1}\right.$ for each) (Ullah et al. 2018). Krall et al. (1996) revealed the importance of sugar beet-mustard intercropping for nematode resistance along with high monetary returns. Intercropping of sugar beet with other crops is a profitable agricultural activity implying benefits from the same land. Studies had revealed that intercropping of sugar beet with several crops help in returning high yields and high monetary benefits that could not be obtained when the crop was grown solely (Singh et al. 1999; Osman and Haggag 2000). Gazdag (2000) showed that intercropping helps in decreasing soil compaction. Improvement in the yield of sugar beet has also been reported in intercropping of sugar beet with garlic or onion (Toaima et al. 2000). The combination of sugar beet with oilseed and oats produced high monetary profits in comparison with intercropping of sugar beet with other crops, particularly sugar beet + wheat (El-Dessougi et al. 2003; Vos and Putten 2004). Azad and Alam (2004) had also illustrated the benefit obtained from the same land when the combination of sugar beet + potato, sugar beet + coriander and sugar beet + onion was grown in Kashmir. A comparison of production cost, returns, and revenue generated by this crop solely or as an intercrop with some other cash crops is illustrated in Table 8.

\section{For Saline Marshy Lands}

Sugar beet crop is well known for its ability to fertile the saline soils by growing under such conditions where other crops fail to prevail (Misra et al. 2020). It is tolerant to saline conditions in later stages of growth. Khayamim et al. (2017) illustrated that salt stress affects more in the establishment growth phase rather than the germination phase. Mass and Hoffmann (1977) reported that the salt tolerance level of sugar beet is $7.0 \mathrm{dSm}^{-1}$. The salt stress tolerance in sugar beet, Beta vulgaris ssp. martima and Beta vulgaris ssp. vulgaris, were found to be dependent on regulation of osmotic potential either by regulation of ions or by absorption of water. The survivability of sugar beet under salt stress conditions on the long-term basis has been reported due to the decrease stomatal conductance, lowered transpiration rate, increased photosynthesis rate (Daoud et al. 2008). Abbas et al. (2012) revealed that under salt stress conditions, increased sodium content and decreased potassium content were seen in sugar beet tolerant to such conditions. In regions of Sundarbans, West Bengal, India, sugar beet varieties, i.e., Pant S-1, Pant S-10, IISR Comp-1, IISR-2, and Mezzanpoly, have been identified for saline and alkaline prone area. Wadeleigh et al. (1952) had revealed the sugar beet performance under alkali, saline and, saline-alkali soils (Table 9). Under Indian agro-climatic conditions, several exotic varieties and, indigenous germplasm (Table 10) have been evaluated for screening for salinity and alkalinity tolerance (Anonymous 1991-92; Anonymous 1993-94). Anonymous (1991-92) had shown that indigenous sugar beet varieties performed better in salt-affected areas of Sri Ganganagar (Table 11).

\section{As Source of Vitamin C}

Dry beet pulp was found to contain about $30 \%$ of galacturonic acid in the form of pectin substances (Anonymous 1946). This acid forms the base for the synthesis of vitamin C. One ton of dry beet pulp is reported to yield $25 \mathrm{~kg}$ of vitamin $\mathrm{C}$.

Table 8 Cost, returns and revenue from intercropping of sugar beet with other crops. Source: Usmanukhail et al. (2013)

\begin{tabular}{lllcccc}
\hline Crop & Sugar beet yield $\left(\mathrm{t} \mathrm{ha}^{-1}\right)$ & Intercrop $\left(\mathrm{t} \mathrm{ha}^{-1}\right)$ & Production Cost (Rs.) & Gross Revenue (Rs.) & Net Returns (Rs.) & BC Ratio \\
\hline Sugar beet & 76.5 & 0.0 & $45,056.0$ & $114,995.0$ & $69,939.3$ \\
SB + Wheat & 70.3 & 2.5 & $183,377.0$ & $132,261.0$ & $86,417.7$ \\
SB + Barley & 69.5 & 1.5 & $45,353.0$ & $465,468.0$ & $74,782.7$ \\
SB + Lentil & 75.0 & 0.4 & $45,909.0$ & $129,573.7$ & $83,665.3$ \\
\hline
\end{tabular}


Table 9 Sugar beet yield, sucrose content and ionic content in different soil conditions. Source: Wadeleigh et al. (1952)

\begin{tabular}{lllllr}
\hline Soil condition & Yield Lbs/10 foot row & Sucrose content (\%) & \multicolumn{3}{l}{ Cationic content of leaves and petioles } \\
\cline { 5 - 6 } & & & $\mathrm{Na}+$ & $\mathrm{K}+$ per 100 gm & $\mathrm{Ca} \mathrm{dry} \mathrm{wt}$ \\
\hline Alkali & 51.7 & 13.9 & 270 & 80 & 36 \\
Saline & 38.9 & 14.3 & 336 & 81 & 44 \\
Saline alkali & 33.5 & 12.6 & 369 & 65 & 53 \\
Control & 69.0 & 13.4 & 160 & 136 & 48 \\
\hline
\end{tabular}

Table 10 Screening of sugar beet exotic and indigenous varieties for salinity and alkalinity tolerance. Source: Network research project on sugar beet Report, 1991-92 \& 1993-94

\begin{tabular}{|c|c|c|c|c|c|}
\hline Varieties & Root yield $\left(\mathrm{t} \mathrm{ha}{ }^{-1}\right)$ & Total soluble solids $(\%)$ & Root weight (g) & Root girth $(\mathrm{cm})$ & Root length $(\mathrm{cm})$ \\
\hline \multicolumn{6}{|l|}{ Exotic varieties } \\
\hline M. ultramono & 27.5 & 14.9 & 328 & 25.4 & 22.1 \\
\hline M. perma & 26.3 & 15.3 & 417 & 24.5 & 22.0 \\
\hline Marathon & 26.3 & 14.5 & 472 & 26.5 & 20.5 \\
\hline M 8603 & 28.2 & 17.0 & 342 & 22.6 & 21.6 \\
\hline Marita & 31.3 & 15.1 & 492 & 27.3 & 20.4 \\
\hline R 06 & 31.9 & 15.4 & 525 & 30.5 & 25.7 \\
\hline \multicolumn{6}{|c|}{ Indigenous germplasm } \\
\hline LKS-10 & 20.0 & 16.4 & 221 & 15.5 & 14.5 \\
\hline LKS-II & 19.3 & 15.7 & 258 & 23.0 & 15.0 \\
\hline Pant S 10 & 19.0 & 16.4 & 186 & 22.6 & 16.2 \\
\hline IISR Comp-1 & 18.0 & 16.1 & 131 & 18.5 & 12.1 \\
\hline LS-6 & 21.2 & 13.3 & 220 & 15.0 & 13.3 \\
\hline
\end{tabular}

Table 11 Response of Indigenous varieties in salt affected soil of Sri Ganganagar. Source: Network research project on sugar beet Report, 1991-92

\begin{tabular}{lllllll}
\hline Varieties & Root yield $\left(\mathrm{t} \mathrm{ha}^{-1}\right)$ & Sucrose $(\%)$ & Gross sugar $\left(\mathrm{t} \mathrm{ha}^{-1}\right)$ & Alpha amino-N $(\mathrm{ppm})$ & $\mathrm{K}(\mathrm{ppm})$ & $\mathrm{Na}(\mathrm{ppm})$ \\
\hline LKS-10 & 53.6 & 14.2 & 7.6 & 288 & 1800 & 620 \\
LKS-11 & 54.2 & 14.8 & 8.0 & 232 & 600 \\
IISR Comp-1 & 54.2 & 15.2 & 8.2 & 200 & 1760 \\
LS-6 & 52.4 & 14.8 & 7.7 & 224 & 1700 & 560 \\
\hline
\end{tabular}

\section{As Pectin Glue}

Sugar beet pulp is used as pectin glue. This glue can be used as an adhesive in beauty products and as printing ink. May (2011) reported that $100 \mathrm{kgs}$ of beet pulp yield $10 \mathrm{~kg}$ of pectin blue. Though beet pectins contain poor settling qualities, but yet it can be used in yogurt preparation. Ovodov (2009) showed that sugar beet pectins play an important role as emulsifiers having low gelatin properties.

\section{As Bio-Plastics Producer}

Bio-plastics are also produced from sugar beet pectins and pulp. Studies showed that the thermoplastic films are produced from sugar beet pulp using plasticizers (Liu et al. 2011b; Rouilly et al. 2006, 2009). Sugar beet pulp in combination with polylactic acid helps in the production of polymer composites (Chen et al. 2008). This composite had tensile properties that were similar to that in commercially available plastics (Finkenstadt et al., 2008). Liu et al. (2011a) illustrated the use of sugar beet pulp as a co- 
polymer instead of filling material in PLA and polyhydroxyalkanoates (PHA). Castilho et al. (2009) revealed that the cost of PHA production from sugar beet to be $\$ 1.40$ per kg approx. Pavier and Gandini (2000) illustrated that sugar beet pectin can be used as a polyol source.

\section{As Bio-Gas Producer}

Bio-gas production occurs in the sugar factory by fermentation of wastewater by the anaerobic water treatment process. It is an eco-friendly product that helps in reducing the usage of fossil fuel. Bio-gas contains $75 \%$ of methane. Certain sugar beet-producing countries use beet tails and its other parts for the production of bio-gas. This crop contains high amount of carbohydrates that are fermentable (Starke and Hoffmann, 2011) and has an increasing impendency as bio-ethanol substrate (Sieling et al. 2013; Starke and Hoffmann 2011; Weiland 2010). Jacob et al. (2017) shown that in Germany sugar beet contributes to a share of $2 \%$ as a bio-gas producer. Even in places where the utilization of pulp as fodder material has not been done, the pulp is used for producing bio-gas. Ahmed et al. (2016) revealed that silage of sugar beet is an intensely better option as a silage component with maize silage rather than with grass silage. Even a low ratio of maize and sugar beet silage combination will be a better alternative in enhancing the production of biogas. Nges et al. (2012) showed that co-ensilaging of maize and sugar beet improves biogas production by increasing the content. Bottcher et al. (2013) illustrated that when sugar beet silage was added less than $20 \%$, a rise in methane content was seen, but when the addition was increased to $50 \%$, the process became unstable. Nges et al. (2012) further stated that during the mono-digestion process, the occurrence of viscosity during biogas production was reduced by usage of sugar beet silage.

\section{As Detergents}

Sugar beet pectins obtained from pulp are appropriate as an essential ingredient for dishwashing detergents and leather production. The pectins provide functional substitutes for non-degradable polymers, making it more environmentally feasible (Broek and Haveren 2019). Contribution of the bio-based ingredient is relatively higher and the product so obtained is easily degradable through biological means (Brouwers 2019). Application of sugar beet microfibers has been reported to be utilized in detergent production as structurant. Betafib ${ }^{\circledR}$ MCF and BetaBind- $A \AA$ are some of its commercially available products. Brouwers (2019) also shown the usage of bio-based pectins in leather industries for the production of leather. The pectins used, help in influencing the color intensity during this process.

\section{As Food and Baking Ingredients}

Sugar beet fiber contains functional dietary fibers and other soluble and insoluble fibers that serve as an essential ingredient in meat, baking and, other food items. As it has good water holding capacity it helps in kneading dough which is the main essential ingredient in the baking industries. Fibrex ${ }^{\circledR}$ is one such commercially available product containing sugar beet fiber. It also functions as a concentrated dietary fiber in gluten-free products depicting the health importance (Krick 2017). It is also used in buns and cakes. In small quantities, Fibrex ${ }^{\circledR}$ produces a good taste and softness (Anonymous 2011). Cappa et al. (2013) illustrated the improvement of dough workability on the addition of sugar beet fiber. Generally, gluten-free diet (low intake of protein and fiber) is recommended to celiac patients (Cappa et al. 2013). Djordjevic et al. (2018) also showed the importance of sugar beet fiber with sufficient water quantity in gluten-free bread. Addition of this fiber helped in enhancing the nutritional value of the product without hampering any bread quality. Simovic et al. (2016) had also illustrated the positive effect of the combination of sugar beet fiber and carob flour in the production of bread. Tredger et al. (1991) revealed that when $20 \mathrm{~g}$ of sugar beet fiber is used as a dietary supplement, positive results were obtained on cholesterol, and apoprotein levels. The bread obtained by using sugar beet pectin has increased bread volume, soft in texture and, lesser staling properties. Sugar beet pectin contains ferulic acid ( $0.6 \mathrm{wt} \%$ to about $3 \mathrm{wt}$ $\%)$. This component is absent in pectin extracted from citrus pulp or fibers. Sugar beet pectin contains about 0.6 wt $\%$ to about $3 \mathrm{wt} \%$ of ferulic acid (Christensen 2006). Bichsel et al. (1990) showed that products made from sugar beet pulp or whole sugar beet had high mineral ingredients such as magnesium, iron, copper, zinc, or manganese. Liu et al. (2007) demonstrated the use of beet pectin for packaging food items to protect it from active ingredients from thermal shock.

\section{In Paper and Board Manufacturing}

Sugar beet pectin is an important ingredient in paper and board manufacturing due to its favorable physical-chemical properties. It is used as an anionic surface-active agent. Many studies have shown the precise effect of the application of pectin and hemicelluloses as a surface treatment for the production of paper (Aaltio and Jounikainen 1971; Hernadi and Erdelyi 1971; Guha and Pant 1970). The results were dependent on the pulp grade, quantity and, type of the substance used. Micronized bleached beet pulp is also used as an additive in white boards and, paper manufacturing (Vaccari et al. 1994). The paper produced from beet pulp is relatively higher resistant, less expensive, 
Table 12 Molasses as a raw material for lactic acid (LA) production. Source: Tomaszewska et al. (2018)

\begin{tabular}{llll}
\hline Raw material & Micro-organism & LA yield $\left(\mathrm{gg}^{-1}\right)$ & Productivity \\
\hline Sugarcane molasses & Bacillus coagulans & 0.88 & 2.1 \\
& Lactobacillus delbrueckii Uc-3 & 0.95 & 4.15 \\
Beet molasses & Lactobacillus delbrueckii IFO 3202 & 0.77 & 4.83 \\
\hline
\end{tabular}

and higher economic value. The paper obtained is recyclable (Monegato and Stagliotto 1997). Fiserova et al. (2007) revealed the importance of sugar beet pulp in paper manufacturing as beet pulp constitutes $30 \%$ of pectin. The white, ivory color of sugar beet pulp gets changed to grayish or blackish in color, known as melanines, due to enzymatic activities of tyrosine. Also, this enzyme is often exposed to air during the process of pulp drying, which converts it to dark color (Fiserova et al. 2007). Furthermore, the size of the beet particle also plays an important part in paper manufacturing.

In the case of white boards, the addition of $8 \%$ of pulp articles helps in increasing the bulk properties, does not damage the strength properties of the board (Krick 2017). Beet pulp has also been used as a packaging material and much more sustainable compared to wood fibers. The alternative of beet pulp as a fiber material has much more potential than that of wood fibers. One of the benefits of using beet pulp fiber as a packaging material is it can be used in packing food-stuffs.

\section{Lactic Acid Production}

Lactic acid is one of the many fermentation products which could be obtained from sugar beet juice (Koch and Venus 2014). The lingo-cellulosic biomass serves as a raw material for the production of lactic acid. The sugar beet pulp is one such example (Tomaszewska et al. 2018). Dry beet pulp contains 22 to $24 \%$ cellulose and $30 \%$ hemicellulose on a weight basis along with other polysaccharides, protein, lignin, and fat contents, though the content of fat, protein, and ash were less (Olmos and Hansen 2012). The beet molasses also consists of some amount of sugars which makes it a good medium for fermentation by different bacteria which helps in the production of lactic acid (Table 12). In a continuous fermentation, $3916.91 \mathrm{~g}$ of sugars will produce $2781.01 \mathrm{~g}$ of lactic acid when Bacillus coagulans was used as a fermenting agent (Oliveira et al. 2020). Bonelli and Gulinelli (1918) described the lactic acid production by fermentation of raw sugar beet. Zakharov and Federova (1946) revealed the comparison of fermentation methods from sugar beet to ethanol and sugar beet to lactic acid. The results showed that the process was difficult in the latter than in the former.

\section{Other Miscellaneous Uses}

Sugar beet is known for its rich nutritional value of betaine. Mikos et al. (2015) revealed that its importance as a nutrition supplement. El-Maghraby et al. (2013) had also identified the suitability of sugar-beet filter cake as novel starting material in the preparation of anorthite bodies. In this process, the filter cake is utilized as a source of calcium oxide. Perzon et al. (2020) illustrated another use of sugar beet waste in the production of cellulose nano-fibers. Alexandri et al. (2019) demonstrated sugar beet pulp as a good option as a feedstock material for succinic acid production.

\section{Constrains in Sugar Beet Production and Cultivation}

Sugar beet crop though having multiple uses is not being picked up much by farmers for cultivation for commercial purposes as there is a lack of market. Being an industrial crop, there is no incentives or seed money sanctioned to the industries for installing the additional machinery required for beet processing by the government. Also, there is no such governmental policy been involved in establishing this crop for commercial purposes. There is a need for government to involve in this crop considering its rich byproducts and ethanol production which will fulfill the future needs of the country. Thus, the government comes forth with grants/easy loans, tax holidays, seed subsidies, etc. for the cultivation of this crop. Until and unless this will be done, this crop will not get that much importance which it actually persists, regardless of how much well it can perform under Indian agro-climatic conditions. There is a need for the creation of a business model in combination with contract farming where several stakeholders commit themselves to their specific role in the entire venture. Earlier such ventures were initiated at Sri Ganganagar among farmers, factory, and seed companies but later it could not facilitate much. 


\section{Prospects and Future Thrust}

Sugar beet has the prospective of becoming an important and feasible crop of our country. The majority of the segments are now worked out and can be coordinated in a mission mode with the suitable government strategies combined with business approach and agricultural department. To encourage the farmers to bring more area under sugar beet crop, IISR, Lucknow has taken initiative in introducing sugar beet in Bihar also with sugar factories with diffusion plants. Further to promote the research and diverse utilization of this crop, IISR, Lucknow has organized a National consultation, a summer school for researchers, and an IISR-Industry interface with researchers, industries of sugar, bio-ethanol, and seed for scientific footing and popularization of this crop in India. The saline and alkaline tolerance capability of this crop are one of the characteristic features of this crop that will help in reclaiming and ploughing saline soils, covering an area of 6.7 million hectares. The integration of sugar beet with other crops has also flourished well as sugar beet turns out to be a profitable crop while intercropping with other crops, not affecting the current cropping pattern. This crop is known to increase the sugar production when intercropped with sugarcane that will definitely help in fulfilling the required increasing demand for sugar and ethanol. It will also help in lowering the burden imposed on a single sugarcane crop for the production of sugar and ethanol. With the increasing demands of sugar beet seed, there will be higher possibilities of shifting multinationals seed companies to shift in India for its seed production and easy availability.

\section{References}

Aaltio, E., and P. Jounikainen. 1971. Effect of some polysaccharide addition on properties of paper. Paperi Ja Puи 40: 561-568.

Abbas, F., A. Mohanna, Gh. Al-Lahham, and E. AL-Jbawi. 2012. Osmotic adjustment in sugar beet plant under salinity stress. Journal of Sugar Beet 28 (1): 37-43.

Agrawal, G.K., and R. Rakwal. 2012. Seed Development: Omics Technologies Towards Improvement of Seed Quality and Crop Yield. New York, NY: Springer.

Ahmed, S., D. Einfalt, and M. Kazda. 2016. Codigestion of Sugar Beet Silage Increases Biogas Yield from Fibrous Substrates. Biomedical Research International. Article ID 2147513. https://doi.org/10.1155/2016/2147513.

Alexandri, M., R. Schneider, H. Papapostolou, D. Ladakis, A. Koutinas, and J. Venus. 2019. Restructuring the conventional sugar beet industry into a novel biorefinery: Fractionation and bioconversion of sugar beet pulp into succinic acid and valueadded coproducts. ACS Sustainable Chemistry \& Engineering 7 (7): 6569-6579.

Anonymous, 1946. Chemical Age, London 51: 35.
Anonymous. 1978-79. Annual Report. Indian Institute of Sugarcane Research, Lucknow, pp. 9-120.

Anonymous. 1988. All India Co-Ordinated Research Project on Sugar Beet (ICAR). General Recommendations, 1988.

Anonymous. 1991-92. Report of Network Research Project on Sugar Beet. IISR Lucknow.

Anonymous. 1993-94. Report of Network Research Project on Sugar Beet. IISR Lucknow.

Anonymous. 2008. Final Report of the APCess Network Project on Sugar Beet "Developing Agro-Techniques for Tropicalized Sugar Beet in India”, (2004-2008), Indian Institute of Sugarcane Research, Lucknow, p 66.

Anonymous. 2010. http://www.esru.strath.ac.uk/EandE/Web_sites/ 02-03/biofuels/quant_bioethanol.htm. 25 May 2010.

Anonymous. 2011. Beet Fibre Makes the Bread Keep Longer. Press Release, 11 April 1996. http://ins-news.com/en/100/19 4/477/Bread-with-beet-fibre-keeps-longer-Security-Safety.htm.

Atiyeh, H., and Z. Duvnjak. 2003. Production of fructose and ethanol from cane molasses using Saccharomyces cerevisiae ATCC 36858. Acta Biotechnologica 23: 37-48.

Azad, M.A.K., and M.J. Alam. 2004. Popularizing of sugarcane based intercropping systems in non millzone. Journal of Agronomy 3 (3): 159-161.

Balan, V.M., V.N. Kirichenko, and L.Y. Zhovtonochuk. 1991. Stand density for seed production sugar beet grown without transplanting. Vestinik Selskogozyaistvennoi Nauki Moskva 7: 97-100.

Baumann, D.T., L. Bastiaans, and M.J. Kropff. 2001. Effects of intercropping on growth and reproductive capacity of late emergingBeta vulgaris $\mathrm{L}$., with special reference to competition for light. Annals of Botany 87: 209-217.

Berghall, S., S. Briggs, S.E. Elsegood, L. Eronen, J.O. Kuusisto, E.J. Philip, T.C. Theobald, and P. Walliander. 1997. The role of sugar beet invertase and related enzymes during growth, storage and processing. Zuckerindustrie 122: 520-530.

Bhattacharya, A.N., T.M. Khan, and M. Uwayjan. 1975. Dried beet pulp as a sole source of energy in beef and sheep rations. Journal of Animal Sciences 41: 616-621.

Biancardi, E., J.M. McGrath, L.W. Panella, R.T. Lewellen, and P. Stevanato. 2010. Sugar Beet. In Root and Tuber Crops, Handbook of Plant Breeding, vol. 7, ed. J.E. Bradshaw, 173-219. New York: Springer.

Bichsel, S.E., M.F. Cleary, R.F. Olson. 1990. Mineral Enriched Sugar Beet. US 4938974, p.15.

Blazek, E. 2007. http://www.appropedia.org/Ethanolfromorganic sugarbeetsCategories.

Bonelli, A., and G. Gulinelli. 1918. The industrial preparation of lactic acid from sugar beets. Indian Chimney Metals 5: 121-124.

Böttcher, R., M. Smieszek, C. Stollberg, and H. Gerath. 2013. Biogas production by co-fermentation of fodder and sugar beet as part of a holistic energy concept in a new greenhouse generation. Agricultural Engineering 45 (1): 28-32.

Brouwers, B. 2019. Beet Pulp as an Alternative to Chemicals in Dishwasher Detergents and the Leather Industry. Sustainability. https://innovationorigins.com/beet-pulp-as-an-alternative-tochemicals-in-dishwasher-detergents-and-the-leather-industry/ \#: :text=Pectins\%20from\%20sugar\%20beet $\% 20 \mathrm{p}$ ulp,de\%20Klok\%20and\%20Smit $\% 20 \% 26 \% 20$ Zoon.

Broek, B.V.D., and J.V. Haveren. 2019. Nieuwe toepassingen voor bietenpulp in vaatwasmiddel en leerindustrie Vaatwastablettenmet bietenpulp, C2W, 2019-11-29, Daniël Linzel, https://www. c2w.nl/nieuws/vaatwastabletten-met-bietenpulp;Nieuwetoepassingen voor bietenpulp in vaatwasmiddel en leerindustrie, Agro \& Chemie, 2019-11-25, https://www.agrochemie.nl/nie uws/nieuwe-toepassingen-voor-bietenpulp-in-vaatwasmiddelen-leerindustrie. 
Cappa, C., M. Lucisano, and M. Mariotti. 2013. Influence of Psyllium, sugarbeet fibre and water on gluten-free dough properties and bread quality. Carbohydrate Polymers 98 (2): 1657-1666.

Castilho, L.R., D.A. Mitchell, and D.M.G. Freire. 2009. Production of polyhydroxyalkanoates (PHAs) from waste materials and byproducts by submerged and solid-state fermentation. Bioresource Technology 100: 5996-6009.

Castle, M.E. 1972. A comparative study of the feeding value of dried sugar beet pulp for milk production. The Journal of Agricultural Science 78 (3): 371-377.

Castle, M.E., M.S. Gill, and J.N. Watson. 1982. Silage and milk production: A comparison between barley and dried sugar beet pulp as silage supplements. Grass Forage Science 36: 319-324.

Chen, F., L. Liu, P.H. Cooke, K.B. Hicks, and J. Zhang. 2008. Performance enhancement of poly (lactic acid) and sugar beet pulp composites by improving interfacial adhesion and penetration. Industrial and Engineering Chemistry Research 47: 8667-8675.

Daoud, S., Ch. Harrouni, B. Huchzermeyer, and H.-W. Koyro. 2008. Comparison of salinity tolerance of two related subspecies of Beta vulgaris: The sea beet (Beta vulgaris ssp. maritima) and the sugar beet (Beta vulgaris ssp. vulgaris). In Biosaline Agriculture and High Salinity Tolerance, ed. Chedly Abdelly, Munir Ozturk, Muhammad Ashraf, and Claude Grignoo. Switzerland: Birkhauser Verlag.

Deol, D.S., and R.S. Kanwar. 1975. Effect of the dates of sowing and harvesting on the yield and quality of sugarbeet. Crop Improvement 2: 105-111.

Djordjevic, M., D.S. Simovic, I. Nikolic, L. Dokic, M. Djordjevic, Z. Seres, and Z. Saranovic. 2018. Rheology and bread-making performance of gluten-free formulations affected by different levels of sugar beet fibre, hydroxypropylmethyl cellulose and water. International Journal of Food Science Technology 53 (8): $1832-1837$.

Dubetz, S., and G.C. Russell. 1964. Soil temperature and nitrogen effect on yield and phosphorus uptake by sugarbeet. Journal of the American Society of Sugar Beet Technology 13: 238-243.

El-Badawi, A.Y., and R.I. El-Kady. 2006. Effect of partial replacement of concentrates with sugar beet pulp on performance, carcass characteristics and energy utilization of growing sheep. International Journal of Agriculture and Biology 8: 344-348.

El-Dessougi, H., A. Dreele, and N. Claassen. 2003. Growth and phosphorus uptake of maize cultivated alone, in mixed culture with other crops or after incorporation of their residues. Journal of Plant Nutrition and Soil Science 166 (2): 254-261.

El-Maghraby, H.F., A.A. Aly, and S.M. Naga. 2013. Utilization of sugarbeet industry by products for production of anorthite. International Ceramic Review 62 (6): 426-428.

FAO 2008. The state of food and agriculture: Biofuel: Prospects, risks and opportunities. Food and Agriculture Organization of the United Nations, Rome. Electronic Publishing Policy and Support Branch Communications Division. FAO. ISBN 978-92-5105980-7. http://www.fao.org/3/i0100e/i0100e.pdf.

FAO, Countries By Commodity, Production, Metadata (2019).

Fares, K., N. Saadaoui, and Q.R. Zina. 2016. Sugar Beet Lime Sludge Composts as Organic Fertilizers. In Proceeding of III International Symposium of Organic Matter Management and Compost Use in Horticulture. eds. M. Cayuela, J.A. Alburquerque, A. Roig, M.A. Sanchez-Monedero. Acta Horticultare 1146: $165-170$.

Finkenstadt, V.L. 2013. A review on the complete utilization of the sugarbeet. Sugar Tech 16 (4): 339-346.

Finkenstadt, V.L., C.K. Liu, P.H. Cooke, L.S. Liu, and J.L. Willett. 2008. Mechanical property characterization of plasticized sugar beet pulp and poly(lactic acid) green composites using acoustic emission and confocal microscopy. Journal of Polymers and the Environment 16: 19-26.

Fiserova, M., J. Gigac, and S. Bohacek. 2007. Application of pretreated sugarbeet pulp in paper manufacture. Cellulose Chemistry and Technology 41 (4-6): 283-289.

Ford-Lloyd, B.V., A.L.S. Williams, and J.T. Williams. 2008. A revision of Beta section vulgaris (Chenopodiaceae) with new light on the origin of cultivated beets. Botanical Journal of the Linnean Society 71 (2): 89-102.

Francis, S.A. 2006. Development of Sugar Beet. In Sugar Beet, ed. A.P. Draycott, 9-29. Oxford: Blackwell Publishing Ltd.

Gazdag, L. 2000. The returns to wheat, maize, sunflower and sugar beet in the KSZE production system. Gazdalkodás 32 (11): $46-48$.

Gibbons, W.R., and C.A. Westby. 1987. Effect of fodder beet cube size on ethanol production via diffusion fermentation. Biotechnology Letter 9 (2): 135-138.

Gressel, J. 2008. Transgenics are imperative for biofuel crops. Plant Sciences 174: 246-263.

Guha, S.R., and P.C. Pant. 1970. Effect of hemicelluloses on properties of paper. Indian Pulp and Paper 25: 385-388.

Gumienna, M., K. Szambelan, H. Jeleń, and Z. Czarnecki. 2014. Evaluation of ethanol fermentation parameters for bioethanol production from sugar beet pulp and juice. Journal of the Institute of Brewing 120 (4): 543-549.

Hemingway, R.G., J.J. Parkins, and J. Fraser. 1986. Sugar-beet pulp products for dairy-cows. Animal Feed Science Technology 15: 123-127.

Hernadi, S., and J. Erdelyi. 1971. Der einfluss des mahlgrades und einiger zusatzstoffe aus die rupffestigkeit des papiers. Papíripar 15: 91-94.

İçöz, E., K.M. Tuğrul, A. Saral, and Ebru İçöz. 2009. Research on ethanol production and use from sugar beet in Turkey. Biomass and Bioenergy 33 (1): 1-7.

Jacobs, A., S. Auburger, E. Bahrs, W. Brauer-Siebrecht, O. Christen, P. Gotze, H.J. Koch, O. Mubhoff, J. Ruckangel, and B. Marlander. 2017. Replacing silage maize for biogas production by sugar beet-A system analysis with ecological and economical approaches. Agricultural Systems 157: 207-278.

Jagosz, B. 2018. Priming improves germination of monogerm red beet (Beta vulgaris L.) clusters. Journal of Animal and Plant Sciences 28: 770-777.

Kaffka, S.R., and D.A. Grantz. 2014. Sugar Crops. In Encyclopedia of Agriculture and Food Systems, vol. 5, ed. N.V. Alfen, 240-260. Amsterdam: Elsevier.

Kapur, R., B.L. Srivastava, and H.M. Srivsatava. 1986. A New Technique for Vegetative Propagation of Sugarbeet Seed Crop. Indian Sugar Crops Journal, 16-17.

Kapur, R., H.M. Srivastava, V.K. Saxena, and S. Bhatnagar. 2000. Adaptability studies for high temperature tolerance of sugarbeet varieties in subtropical India. Crop Improvement 27: 178-186.

Kelly, P. 1983. Sugar beet pulp-A review. Animal Feed Science and Technology 8 (1): 1-18.

Khayamim, S., H. Nshad, M.R. Jahadakbar, and K. Fotohi. 2017. Review on Sugar Beet Salt Stress Studies in Iran. In 3rd International Conference on Agricultural and Biological Sciences (ABS 2017) during 26-29 June 2017. IOP Conf. Series: Earth and Environmental Science, vol. 77, pp. 1-4. IOP Publishing Ltd. https://doi.org/10.1088/1755-1315/77/1/012004.

Koch, T.J., and J. Venus. 2014. Sugar beet syrups in lactic acid fermentation-Part II Saving nutrients by lactic acid fermentation with sugar beet thick juice and raw juice. Sugar Ind./ zuckerindustrie 139 (11): 683-690.

Krall, J.M., D.W. Koch, F.A. Gray, and Yun LiMei. 1996. Potential of sugar beet and mustard for use in sugar beet intercroppings. In Progress in new crops: Proceedings of the Third National 
Symposium New Crops: New opportunities, New Technologies ed. J. Janick. Indianapolis, Indiana, ASHS Press, Alexandria, VA, pp. 619-622.

Krick A. 2017. AWCB Innovation in sugar beet Industry Agrocycle Workshop, Brussels 26th January 2017 https://www.cibe-europ e.eu/img/user/file/015a-17\%20CIBE\%20Presentation\%2 0Agrocycle\%20workshop\%20Jan\%202017.pdf. Accessed 2 June 2021.

Kumar P., A. Bhattacharya, and R. Singh. 2009. Sugar beet. In Kole, C., C.P. Joshi, and D.R. Shonnard (eds). Handbook of Bioenergy Crop Plants, Taylor and Francis e-book, pp. 705-712.

Kumar, S., S. Paroha, and N. Mohan. 2015. Alcohol ProductionAchieving EBP SUCCESS. Powerpoint Presentation, pp. 1-37.

Lal, M., and N. Mukerji. 1998. Productivity of intercropping system in sugarcane with sugar beet and wheat. Madras Agricultural Journal 80 (4): 177-179.

Liu, B., J. Zhang, L. Liu, and A.T. Hotchkiss. 2011a. Preparation and properties of water and glycerol-plasticized sugar beet pulp plastics. Journal of Polymers and the Environment 19: 559-567.

Liu, B., S. Bhaladhare, P. Zhan, L. Jiang, J. Zhang, L. Liu, and A.T. Hotchkiss. 2011b. Morphology and properties of thermoplastic sugar beet pulp and poly (butylene adipate-co-terepthalate) blends. Industrial and Engineering Chemistry Research 50: 13859-13865.

Liu, L.S., V.L. Finkenstadt, C. Liu, T. Jin, M.L. Fishman, and K.B. Hicks. 2007. Preparation of poly (lactic acid) and pectin composite films intended for applications in antimicrobial packaging. Journal of Applied Polymer Science 106: 801-810.

Maas, E.V., and G.J. Hoffman. 1977. Crop salt tolerance-Current assessment. Journal of the Irrigation and Drainage Division 103: 115-134.

Mahmoud, A.E.M., and N. El-Bordeny. 2016. The nutritive value of sugar beet pulp substituted corn for bakri lams. Paksitan Journal of Zoology 48 (4): 995-1002.

Mall, A.K., V. Misra, A.D. Pathak, and Md Shabbudin. 2018b. Identifying and Assessing Sugar Beet Varieties for Sub-Tropical Region of India for High Sucrose Content and Yield. In Souvenir cum Abstract Book of International Conference on Novel Applications of Biotechnology in Agricultural Sectors: Towards Achieving Sustainable Development Goal-2018, Held at Banaras Hindu University During 20-21 March 2018, p. 219.

Mall, A.K., V. Misra, D. Singh, M. Kumar, and A.D. Pathak 2018c. Research, Development and prospects for sugarbeet in India: An Initiatives by IISR. In Shukla, P.S., N. Singh (ed) Conference book International Conference on Agriculture, Allied and Applied Sciences (ICAAS-2018), held at Jawaharlal Nehru University, New Delhi during 28-29 April 2018; p. 128.

Mall, A.K., V. Misra, M. Kumar, and A.D. Pathak. 2018a. Assessment of ethanol Recovery and Juice Quality Parameters in Sugarbeet in Drought Conditions of Sub-Tropical India. In 2nd International Conference on Advances in Agricultural, Biological and Applied Sciences for Sustainable Future (ABAS-2018)Theme I eds. J. Singh, R. Nigam, W. Hasan, A. Kumar, R. Singh, H. Naz, N. Kapoor, S.L. Bairwa, A. Rani, M. Kumar Held at Swami Vivekanand Subharti University, Meerut, U.P., India During 20-22 October 2018, p. 99.

Malnoua, C.S., K.W. Jaggarda, and D.L. Sparkes. 2008. Nitrogen fertilizer and the efficiency of the sugar beet crop in late summer. European Journal of Agronomy 28 (1): 47-56. https://doi.org/10.1016/j.eja.2007.05.001.

Martin-Olmedo, P., F. Cabrera, R. Lopez, and J.M. Murillo. 1996. Residual effects of sugar beet vinasse on plant growth. InFertilizers and Environment, ed. C. Rodriguez-Barueco, 527-531. Kluwer Academic Publishers. https://doi.org/10.1007/97894-009-1586-2 92.
Mathuria, R.S., and R.L. Bhoj. 1977. A note on sugarbeet cultivation in western Uttar Pradesh. Cane Grower's Bulletin 3: 12-14.

May, M. 2011. Sugar Beet. In Energy Crops: Energy and Environment Series, eds. N.G Halford, and A. Karp 3 : 104-115, RSC Publishing.

Maynard, E.J. 1948. Feeding Values of Sugar Beet By-Products. In ASSBT Proceedings 5th General Meeting of American Society of Sugar Beet Technologists, pp. 792-795.

Mehdikhani, P., H. Hovsepyan, and M.R. Bari. 2011. Sugar beet genotype effect on potential of bioethanol production usiing Saccharomyces cerevisiae fermentation. African Journal of Biotechnology 10 (20): 4100-4105.

Mikos, P., A. Antczak-Chrobot, and M. Wojtczak. 2015. Free amino acids, betaine, nitrate and nitrite in the sugar beet processing-A literature review. International Sugar Journal 117 (1403): 790-797.

Misra, V., A.K. Mall, and A.D. Pathak. 2020. Sugarbeet: A sustainable crop for salt stress conditions. In Agronomic Crops, ed. Mirza Hasaanzuman, 40-62. Singapore: Springer Nature Singapore Pte Ltd. Publications.

Misra, Varucha, A.K. Mall, Mukesh Kumar, Drishti Singh, and A.D. Pathak. 2018. Sugar Beet Crop: Asset for Farmers in Enhancing Income. India International Science Festival. Theme Frontier Areas in Science (Book 3) Held at Indra Gandhi Pratishthan, Lucknow; Abstract No. 43, pp. 43.

Mohan, N. 2019. Sugarbeet-A potential feed stock for ethanol production. Sharkara 50 (4): 20-27.

Monegato, A., and F. Stragliotto. 1997. Earth Summit 15, New York, 23-27 June.

Moran-Salazar, R.G., A.L. Sanchez-Lizarraga, J. Rodrigue-Campos, G. Davila-Vazquz, E.N. Marino-Marmolejo, L. Dendooven, and S.M. Contreras-Ramos. 2016. Utilization of vinasses as soil amendment: Consequences and perspectives. Springerplus 5: 1006-1017.

Motiwale, R.S. Chauhan, and V.P. Agnihotri. 1991. The Sugar beet cultivation. Indian Institute of Sugarcane Research Lucknow, p. 14.

Mukhopadhyay, A.N. 1971. Sclerotium root rot of sugarbeet in India. Mycopathology Applicanta 44: 265-370.

Murray, J.M.D., A.C. Longland, and M. Moore-Colyer. 2006. In vitro fermentation of different ratios of high temperature dried lucerne and sugar beet pulp incubated with an equine faecal inoculums. Animal Feed Science and Technology 129 (1-2): 89-98. https://doi.org/10.1016/j.anifeedsci.2005.12.001

Nges, I.A., A. Björn, and L. Björnsson. 2012. Stable operation during pilot-scale anaerobic digestion of nutrient-supplemented maize/sugar beet silage. Bioresource Technology 118: 445-454.

OECD. 2006. Section 8-Sugar Beet (Beta vulgaris L.). In Safety Assessment of Transgenic Organisms, OECD Consensus Documents Vol. 1., pp. 174-196 Paris, France: OECD Publishing. ISBN 9789264095380.

Oliveira, R.A.D., R. Schneider, B.H. Lunelli, C.E.V. Rossell, R.M. Filho, and J. Venus. 2020. A simple biorefinery concept to produce $2 \mathrm{G}$-lactic acid from sugar beet pulp (SBP): A high-value target approach to valorize a waste stream. Molecules 25 (9): 2113.

Olmos, J. Concha., and M.E.Z. Hansen. 2012. Enzymatic depolymerisation of sugar beet pulp: Production and characterization of pectin and pectic-oligosaccharides as a potential source for functional carbohydrates. Chemical Engineering Journal 192: 29-36.

Osman, M.S., and M.E.A. Haggag. 2000. A Study on the Feasibility of Intercropping Sugar Beet with Other Winter Crops. Research Bulletin, 1-7. Cairo: Faculty of Agriculture, Ain Shams University. 
Ovodov, Y.S. 2009. Current views on pectin substances. Russian Journal of Bioorganic Chemistry 35 (3): 269-284.

Panella, L., and S.R. Kaffka. 2011. Sugar beet (Beta vulgaris L.) as bio-fuel feedstock in the United states. In Sustainability of the Sugar and Sugar Ethanol Industries, ed. G Eggleston. ACS Symposium Series, 163-175. Washington DC: American Chemical Society.

Parkins, J.J., R.G. Hemingway, and J. Fraser. 1986. A note on dried molassed sugar beet pulp and unmolassed pressed sugar beet pulp as comparative feeds for dairy cows. Animal Science 43 (2): 351-354.

Paroha, S., and D. Swain. 2020. Alternate feed stocks and their economic sustainability for ethanol production in India. International Journal of Economics, Commerce and Research 10 (2): 87-104.

Pathak, A.D., R. Kapur, R. Kumar, and M.K. Vishwakarma. 2011. Impact of different vernalization treatments on flowering and seed production in sugarbeet (Beta vulgaris L.). Indian Journal of Sugarcane Technology 26 (1): 24-27.

Pathak, A.D., R. Kapur, S. Solomon, R. Kumar, S. Srivastava, and P.R. Singh. 2014. Sugar Beet: A historical perspective in Indian context. Sugar Tech 16 (2): 125-132. https://doi.org/10.100 7/s12355-014-0304-7.

Pathak, A.D., V. Misra, and A.K. Mall. 2017. Prospects of sugarbeet in India. In Proceedings of International Symposium onSugarcane Research Since Co 205:100 Years and Beyond (SucroSym), eds. G. Hemaprabha, R. Viswanathan, T.Ramasubramanian, A. Bhaskaran, K. Mohanraj, B. Rampp. 90-97. ISBN: 978-9385267-12-3.

Pavier, C., and A. Gandini. 2000. Oxypropylation of sugar beet pulp. 1. Optimisation of the reaction. Industrial Crops and Products 12: $1-8$.

Perzon, A., B. Jorgensen, and P. Ulvskov. 2020. Sustainable production of cellulose nanofibre gels and paper from sugar beet waste using enzymatic pre-treatment. Carbohydrate Polymers 230: 115581. https://doi.org/10.1016/j.carbpo 1.2019 .115581

Ranković, J., J. Dodić, S. Dodić, and S. Popov. 2009. Bioethanol production from intermediate products of sugar beet processing with different types of Saccharomyces cerevisiae. Chemical Industry and Chemical Engineering Quarterly 15 (1): 13-16.

Rouilly, A., C. Geneau-Sbarta, and L. Rigal. 2009. Thermo-mechanical processing of sugar beet pulp. III. Study of extruded films improvement with various plasticizers and cross-linkers. Bioresource Technology 100: 3076-3081.

Rouilly, A., J. Jorda, and L. Rigal. 2006. Thermo-mechanical processing of sugar beet pulp I. Twin-screw extrusion process. Carbohydrate Polymers 66: 81-87.

Salazar-Ordonez, Melania, P.P. Perez-Hernandez, and J.M. MartínLozano. 2013. Sugar beet for bioethanol production: An approach based on environmental agricultural outputs. Energy Policy 55: 662-668.

Shapouri, H., M. Salassi, J. Nelson 2006. The economic feasibility of ethanol production from sugar in the United States. Report of USDA. https://www.lsuagcenter.com/NR/rdonlyres/0EF2C03 C-1C69-455E-AB51-C16D165C2F41/28608/ EthanolSugarFeasibilityReport3Julyreleasedcopy.pdf. Accessed 2 June 2021.

Sieling, K., A. Herrmann, B. Wienforth, F. Taube, S. Ohl, E. Hartung, and H. Kage. 2013. Biogas cropping systems: Short term response of yield performance and $\mathrm{N}$ use efficiency to biogas residue application. European Journal of Agronomy 47: 44-54.

Simovic, D.S., S.S. Mozina, P. Raspor, and N. Maravic. 2016. Carob flour and sugar beet fibre as functional additives in bread. Acta Periodica Technologica 47: 83-93.
Singh, Y., G.R. Singh, and P.P. Singh. 1999. Economic evaluation of sugar beet-wheat intercropping. Indian Journal of Agriculture Sciences 54 (9): 718-721.

Smit, A.L. 1983. Influence of External Factors on Growth and Development of Sugar Beet (Beta vulgaris L.). Centre for Agricultural Publishing and Documentation Wageningen, pp. 1-117.

Srivastava, H., M. Sharma, and V.K. Bhargava. 2008. Genetic potential of sugar beet genotypes for ethanol production under different agroclimatic condition of India. In 71st IIRB Congress, p. 55.

Srivastava, H.M. 1990. Development of diploid and polyploid hybrids of sugar beet for sub-tropical climate and their seed production potentials. International Conference on seed Science and technology. International conference on seed science and technology, New Delhi Feb 21-25, 1991. p. 8.

Srivastava, H.M. 1991. Breeding and Improvement of Sugar Beet for Sub Tropical Climate. In 2nd International Beta Genetic Resources Workshop. FAL, Brauns Chweig, Germany, June 24-28, 1991. International Crop Network Series, No. 7, IBPGR 70-71.

Srivastava, H.M. 1995. Sugar beet pre-breeding in India. Journal of Sugar Beet Research 32 (2 \& 3): 99-110.

Srivastava, H.M., B.L. Srivastava, and V.K. Saxena. 1983. Sugarbeet seed production in the Kumaon hills. II. Effect of steckling size and time of transplanting on yield of sugarbeet seed. Indian Sugar Crops Journal 9: 21-24.

Srivastava, H.M., B.L. Srivastava, and V.K. Saxena. 1986. Comparison of in-situ and transplanting methods of seed production of sugarbeet in Kumaon Hills. Indian Journal Agriculture Research 20 (4): 177-181.

Starke, P., and C. Hoffmann. 2011. Sugarbeet as a substrate for biogas production. Sugar Industry 136: 242-250.

Stoyanov, D., I. Atanassova, and S. Stratieva. 1997. Increase of sugar beet and sunflower yields. Pochvoznanie. Agrokhimiya $y$ Ekologiya 3 (3): 16-20.

Tan, L., Zhao-Young. Sun, S. Okamoto, M. Takaki, Yue-Quin. Tang, S. Morimura, and K. Kida. 2015. Production of ethanol from raw juice and thick juice of sugar beet by continuous ethanol fermentation with flocculating yeast strain KF-7. Biomass and Bioenergy 81: 265-272.

Theurer, J.C., D.L. Doney, G.A. Smith, R.T. Lewellen, G.J. Hogaboam, W.M. Bugbee, and J.J. Gallian. 1987. Potential ethanol production from sugar beet and fodder beet. Crop Science 27 (5): 1034-1040.

Toaima, S.E.A., K.A. El-Douby, and A.I. Nafei. 2000. Intercropping sugar beet with minor crops: Intensification treatments. Sugar Crops 21 (3): 23-25.

Tomaszewska, J., D. Bielinski, M. Binczarski, and J. Berlowska 2018. Products of sugar beet processing as raw materials for chemicals and biodegradable polymers. RSC Advances 8 (6): 3161-3177.

Tredger, J.A., L.M. Morgan, J. Travis, and V. Marks. 1991. The effects of guar gum, sugar beet fibre and wheat bran supplementation on serum lipoprotein levels in normocholesteroalemic volunteers. Journal of Human Nutrition and Dietetics 4 (6): 375-384.

Turquois, T., M. Rinaudo, F.R. Taravel, and A. Heyraud. 1999. Extraction of highly gelling pectic substances from sugar beet pulp and potato pulp: Influence of extrinsic parameters on their gelling properties. Food Hydrocolloids 13: 255-262.

Ullah, S., E.A. Khan, G. Jilani, M. Panhwar, and N. Shakoor. 2018. Sugarcane-sugarbeet intercropping augments cumulative crop/sugar production and financial turnovers under enhanced fertilization. Sugar Tech 20: 431-438. https://doi.org/10.1007/s123 55-017-0551-5. 
Christensen, J.A.S. 2006. US20060216388A1. Bread compositions containing sugar beet pectins. March 17, 2006https://patentim ages.storage.googleapis.com/6b/1f/f0/31c3db33be84b4/US200 60216388A1.pdf. Accessed 3 june 2021.

USDA. 2008. Agricultural Statistics. United States Government Printing Office, Washington, DC. ARS Publication. Wide Cross. htm. Available online.

Usmanikhail, M.U., S.D. Tunio, G.H. Jamro, F.C. Oad, S.W.U. Hassan, Q.D. Chachar, and M.A. Khanzada. 2013. Effect of intercropping cereals and lentil in sugar beet on yield and monetary benefits. Pakistan Journal of Botany 45 (2): 401-406.

Vaccari, G., C. Nicolucci, and G. Mantovani, and A. Monegato. 1994. Process for manufacturing paper from sugar-beet pulp and paper thus obtained. European Patent EP0644293B1, 1994-09-17. https://patentimages.storage.googleapis.com/b9/73/af/ edfde7d839ea9c/EP0644293B1.pdf. Accessed 3 June 2021

Von Felde, A. 2008. Trends and developments in energy plant breeding-special features of sugar beet. Zukerindustrie 133: 342-345.

Vos, J., and P.E.L. Putten. 2004. Nutrient cycling in a cropping system with potato, spring wheat, sugar beet, oats and nitrogen catch crops. II. Effect of catch crops on nitrate leaching in autumn and winter. Nutrient Cycling in Agroecosystems 70 (1): 23-31.

Wadleigh, C.H., A.D. Ayers, and C.A. 1952. Effect of saline and alkali soil on growth of sugar beets. In Proceeding American Society of Sugar beet Technologists, vol. 7, pp. 50-54.

Webster, T.M., T.L. Grey, B.T. Scully, and W.C. Johnson. 2016. Yield potential of spring harvested sugar beet (Beta vulgaris) depends on autumn planting time. Industrial Crops and Products 83: 55-60.

Weiland, P. 2010. Biogas production: Current state and perspectives. Applied Microbiology and Biotechnology 85: 849-860.

Zakharov, I.P., and M.F. Federova. 1946. Production of lactic acid from sugar beet and cases of inactivation of lactic acid fermentation. Mikrobiologiya 15 (1): 57-66.

Zicari, S., R. Zhang, and S. Kaffka 2019. Sugar Beet. In Integrated Processing Technologies for Food and Agricultural By-Products. eds. Z. Pan, R. Zhang, and S. Zircari, 331-351. https://doi.org/10.1016/b978-0-12-814138-0.00013-7.

Publisher's Note Springer Nature remains neutral with regard to jurisdictional claims in published maps and institutional affiliations. 